\title{
Editorial
}

\section{Alternatives to epidural analgesia during labour}

\section{"Pain has an Element of Blank - It cannot recollect \\ When it began, or if there were A time when it was not."}

EMILY DICKINSON

The intensity of labour pain is greater than that for most acute and chronic pain syndromes. 'As such, it is a powerful stimulus and may produce undesirable effects in the mother and fetus. ${ }^{2}$ These include increases in maternal blood pressure, cardiac output and catecholamine release. Maternal hyperventilation during contractions followed by periods of hypoventilation during uterine relaxation may cause a decreased maternal $\mathrm{PaO}_{2}$ during the relaxation phase with a corresponding decrease in fetal oxygenation. Hyperventilation also causes a maternal respiratory alkalosis which has the potential to decrease umbilical blood flow and oxygen transfer to the fetus.

Effective analgesia, through elimination of the pain component, may: (1) interrupt the hypo-hyperventilation cycle with normalization of maternal $\mathrm{PaCO}_{2}$ and $\mathrm{PaO}_{2}$, (2) decrease catecholamine release, (3) offset that portion of increased cardiac output secondary to pain, and (4) improve circulation and oxygenation to the fetus.

Epidural analgesia provides excellent pain relief for the parturient with minimal side-effects and has achieved popularity in obstetric units throughout the country. However, provision of epidural analgesia is not always feasible nor is it applicable to all situations. Many small communities have active obstetric units but limited availability of anaesthetic personnel. ${ }^{3}$ With a relatively small obstetric case load it may not be possible to maintain the necessary skills to provide safe, effective epidural anaesthesia. ${ }^{4}$ As well, epidural anaesthesia is contraindicated in situations of patient refusal, presence of coagulopathy or infection, and haemodynamic instability. Under these circumstances, other analgesic modalities must be used, either alone or in combination. Psychoprophylaxis (Lamaze) and TENS (Transcutaneous Electrical

Division of Obstetric Anaesthesia,the Universily of British Columbia and Grace Hospital, Vancouver, British Columbia.
Nerve Stimulation) are non-pharmacological options, while inhalational analgesia with nitrous oxide/oxygen mixtures, and systemic or spinal narcotics provide more potent pain relief.

Psychoprophylaxis (Lamaze) is a drug-free technique based on decreasing or eliminating pain and anxiety during labour. To be effective the parturient must be highly motivated. In late pregnancy, the parturient and her partner participate in lectures on the anatomy and physiology of labour and delivery, the causes of pain, and exercises to promote relaxation and distraction. Advantages include lower pain scores ${ }^{\prime}$ and more informed and cooperative patients. Fatigue may counteract the beneficial effects during long, difficult labours.

Described as a form of "electrical acupuncture," TENS has the advantage of simplicity and of being nondepressant to the fetus and mother. For the first stage of labour, electrodes are placed over the $\mathrm{T}_{10^{-}} \mathrm{L}_{1}$ dermatomes on either side of the spine and low intensity stimulation is used continuously. A higher level is switched on during contractions. A blinded study involving TENS and TENS placebo did not demonstrate any difference in pain relief but patient satisfaction and acceptance was high. ${ }^{5}$ Previous training is said to increase its effectiveness. The major disadvantage is interference with electronic fetal monitoring.

Intermittent inhalation of a $50 \%$ mixture of nitrous oxide and oxygen provides effective analgesia in approximately $40 \%$ of parturients. ${ }^{6}$ The advantages of rapid pulmonary uptake and excretion, self-administration and a proven safety record make it a particularly useful technique. For maximum benefit, the parturient applies the mask tightly to her face and, beginning with the onset, breathes rapidly and deeply throughout the contraction. Symptoms of hyperventilation and drowsiness may occur with prolonged use.

Narcotics have been used effectively for labour pain for many years. Systemic administration of these agents has fallen into disfavour because of the frequency of maternal side-effects (nausea, vomiting, dysphoria, drowsiness) and the potential for neonatal respiratory depression and prolonged neurobehavioural changes.

Small doses of intrathecal morphine $(0.2-1.0 \mathrm{mg})$ have 
been used in the parturient where sympathetic blockade has been undesirable. ${ }^{7}$ Prolonged, effective first-stage analgesia is achieved but with a high incidence of maternal side-effects (nausea, vomiting, pruritus). Local infiltration of the perineum and/or pudendal nerve block are required for second stage anaesthesia. This technique is easy to perform and the use of a 25- or 26-gauge needle lessens the risk of spinal headache and epidural venipuncture. One case of severe respiratory depression has been reported. $^{8}$

The case report by Kleiman et al., ${ }^{9}$ in this issue of the Journal, focuses attention on another variation of narcotic analgesia: PCA (patient-controlled analgesia) fentanyl for a parturient with a contraindication to epidural analgesia. Intravenous administration bypasses many of the disadvantages associated with intramuscular narcotics. Absorption is more predictable and precise titration to analgesic effect may be achieved. PCA has the additional advantage of increased patient satisfaction over other techniques when used to treat postoperative pain. ${ }^{10}$ The presence of the "lockout period" prevents selfadministration of large doses. Previous reports of PCA for labour are few and have involved narcotics other than fentanyl.

The advantages of fentanyl in labour include rapid onset, short duration of action, and lack of active metabolites. ${ }^{9}$ The short duration of action is secondary to redistribution with uptake into maternal tissues. Maternal side-effects include sedation and pruritus but these are generally mild and require no treatment. Nausea and vomiting are reportedly less than with meperidine." There is the possibility of profound respiratory depression so the mother should be closely monitored.

Fentanyl rapidly crosses the placenta, appearing in the fetal circulation in less than one minute ${ }^{12}$ and may cause a decrease in the beat-to-beat variability of the fetal heart rate. ${ }^{13}$ As a similar pattern occurs with fetal acidosis and hypoxaemia, careful assessment should be undertaken to prevent unnecessary obstetric intervention. Caution in its use is advised if the fetus is premature or if there is fetal acidosis which may cause "trapping" of fentanyl in the fetal circulation. The brain of the neonate is sensitive to the depressant effects of narcotics and respiratory depression may occur.

Some of the questions which are still unanswered with respect to the use of PCA fentanyl in labour include:

1 What type of monitoring is appropriate for the mother and the newborn?

2 What is an appropriate length of time to monitor the neonate?

3 What are appropriate dosage schedules and lockout times to ensure adequate maternal analgesia with minimal fetal and neonatal effects?
The need for close maternal and fetal monitoring should not be a contraindication to this technique. Parturients receiving continuous lumbar epidural analgesia are closely watched for evidence of ascending level of block and hypotension. With PCA narcotics, the respiratory rate and level of consciousness need to be similarly monitored. Well-designed studies and additional case reports will allow proper assessment of the risks and benefits of this technique in labour.

In conclusion, effective analgesia is advantageous to the parturient and her fetus. As physicians involved in the provision of pain relief, we must be familiar with alternatives to epidural analgesia. Early anaesthetic consultation will allow assessment of the parturient to determine the best analgesic modality. Well-motivated parturients may find the non-pharmacological methods satisfactory during early labour but may require more potent analgesia as labour progresses. PCA narcotics are a logical alternative provided there is adequate maternal and newborn monitoring.

\section{Contre les douleurs de l'accouchement, l'arsenal s'élargit}

Les douleurs de la femme en travail sont parmi les pires qui soient' ${ }^{\prime}$ et elles peuvent être nocives pour la mère et son enfant. ${ }^{2}$ La stimulation adrénergique qu'elles provoquent amène une augmentation du débit cardiaque et de l'hypertension maternelle. L'hypoventilation qui suit l'épisode d'hyperventilation associé à la contraction utérine peut entraîner une baisse la $\mathrm{PaO}_{2}$ maternelle et conséquemment, une diminution de l'oxygénation du fœtus. L'hyperventilation peut faire de même en induisant une alcalose respiratoire qui réduit le flot sanguin ombilical.

Une analgésie efficace peut donc: 1) interrompre le cycle hyper-hypoventilation et régulariser la $\mathrm{PaO}_{2}$ et la $\mathrm{PaCO}_{2}$ maternelles, 2) diminuer la libération de catécholamines, 3) limiter l'augmentation du débit cardiaque en partie attribuable à la douleur et enfin, 4) améliorer le transport d'oxygène vers le foetus.

L'analgésie épidurale est très efficace pendant le travail et présente peu d'effets secondaires, ce qui explique sa popularité dans les salles d'accouchements canadiennes. Toutefois, elle est parfois inapplicable ou il est impossible 
de l'offrir. Certaines petites communautés peuvent offrir des soins obstétricaux mais doivent composer avec des effectifs anesthésiques limités. ${ }^{3}$ Parfois, un débit de cas insuffisant ne permets pas de maintenir l'habileté nécessaire pour assurer la sûreté de l';intervention anesthésique. ${ }^{4}$ La parturiente peut refuser d'avoir recours à une épidurale ou cette dernière peut être contre-indiquée lorsque il y a une infection, une coagulopathie ou de l'instabilité hémodynamique. C'est alors qu'il faut pouvoir avoir recours à d'autres modes d'analgésie. La psychoprophylaxie ou méthode de Lamaze et le TENS ("transcutaneous electrical nerve stimulation") ne font appel à aucun médicament mais l'inhalation de mélange d'oxygène et de protoxyde d'azote ou l'injection parentérale ou intrathécale de morphiniques est plus efficace.

La psychoprophilaxie (Lamaze) vise à réduire voire à éliminer l'anxiété et la douleur durant le travail. Pour être efficace, elle requiert une grande motivation de la part de la parturiente que doit dans les derniers mois de sa grossesse assister avec son conjoint à des cours sur l'anatomie et la physiologie du travail et de l'accouchement et sur les mécanismes de la douleur. Elle y apprend aussi des exercises de relaxation. Avec celte méthode, les patientes sont mieux informées, peuvent mieux participer et ont moins mal.' Cependant, la fatigue d'un travail long et difficile peut venir à bout de la meilleure préparation.

Le TENS, cette espèce d'acupuncture électrique, est simple et n'induit aucune dépression maternelle ou fœtale. Pendant la première phase du travail, on place les électrodes d'un coté ou l'autre de la colonne dans la région de $T_{10}-L_{1}$ et on y fait passer en continu, un courant de faible intensité que l'on augmente pendant les contractions. Toutefois, dans le cadre d'une élude à double insu, on n'a pas pu observer d'effet objectif du TENS sur la douleur, malgré la satisfaction des patientes. ${ }^{5}$ On rapporte que la pratique peut en augmenter l'efficacité mais le TENS interfère souvent avec la surveillance électronique du foetus.

L'inhalation intermittente d'un mélange à parts égales de protoxyde d'azote et d'oxygène parvient à soulager près de $40 \%$ des parturientes. ${ }^{6}$ L'auto-contrôle, une absorption et une excrétion pulmonaire rapide de même que son caractère bénin contribuent à l'utilité de cette technique. Pour en tirer avantage, la patiente doit s'appliquer étanchément le masque sur le visage au début de la contraction et respirer rapidement et profondément pendant toute la contraction. Peuvent survenir à l'occasion des symptômes d'hyperventilation et de la sédation.

II y a longtemps qu'on a découvert l'efficacité des morphiniques à contrer les douleurs du travail. Toutefois, leurs nombreux effets secondaires maternels (nausées, vomissements, dysphorie et sédation) et fataux (dépres- sion respiratoire et modifications du comportement) en ont discrédité l'usage systémique

On a pourtant utilisé de la morphine par voie sousarachnoïdienne $(0,2-1,0 \mathrm{mg})$ chez les parturientes à qui on voulait éviter un bloc sympathique. ${ }^{7}$ On produisait ainsi une analgésie prolongée et efficace pendant le premier stage du travail mais trop souvent au prix d'effets secondaires ennuyeux (nausées, vomissements, prurit). De plus, on devait y adjoindre un bloc honteux et/ou une infiltration du périné lors du deuxième stage. ${ }^{8}$

Vous trouverez plus loin dans ce numéro du Journal, l'article de Kleiman et al. ${ }^{9}$ qui apporte une variante à l'usage des morphiniques pendant le travail. Les auteurs ont utilisé du fentanyl en mode d'auto-analgésie (PCA pour "patient controlled analgesia ") chez une patiente qui ne pouvait avoir d'épidurale. Avec les morphiniques, la voie intraveineuse permets d'éviter plusieurs des inconvénients de la voie intramusculaire. L'absorption est plus rapide et prévisible et on peut titrer le médicament jusqu'à l'effet escompté. De plus lorsque qu'il s'agit de soulager les douleurs postopératoires, les patients préfèrent l'auto-analgésie aux autres modes d'analgésie. ${ }^{10} \mathrm{La}$ programmation d'un intervalle minimum obligatoire entre deux doses évite le surdosage. Jusqu'à maintenant, on n'avait que très peu d'expérience avec l'autoanalgésie pendant le travail, et jamais n'avait on utilisé le fentanyl.

Dans un contexte de travail, le fentanyl qui n'a pas de métabolites actifs, offre une action rapide mais courte en raison de sa redistribution à d'autres tissus maternels. " La sédation et le prurit qu'il peut causer sont habituellement légers et ne requièrent pas de traitement. De plus il n'entraïne probablement pas autant de nausée et de vomissement que la mépéridine. " Un risque de dépression respiratoire grave existe toutefois et justifie une surveillance appropriée.

Le fentanyl traverse rapidement le placenta et en moins d'une minute, on le retrouve dans la circulation fatale. ${ }^{12}$ Il peut émousser la variabilité du rythme cardiaque du fœtus $^{13}$ à l'instar d'un épisode d'acidose ou d'hypoxémie fœtale et on devra alors éviter une intervention intempestive. La prématurité ou une acidose du fœtus peuvent favoriser l'accumulation du fentanyl dans ses tissus. De plus les centres respiratoires du fotus sont sensibles au fentanyl et on peut y entraïner une dépression respiratoire.

On devra s'intéresser à certains aspects de l'usage du fentanyl en autoanalgésie pour soulager les douleurs du travail soit:

I Le type de monitorage nécessaire pour la surveillance de la mère et du fôetus.

2 La durée minimale de surveillance respiratoire du nouveau-né.

3 Les paramétres pour un usage optimal (dose, intervalle minimum obligatoire) permettant une analgésie adé- 
quate tout en minimisant les effets secondaires sur l'enfant à naïtre.

Il ne faut toutefois pas faire tout un plat de la nécessité de surveiller la mère et son fœtus de près puisqu'on s'y prête déjà lors de l'analgésie épidurale continue, à l'affût de l'hypotension et d'un bloc qui monte trop haut. Avec les morphiniques en autoanalgésie, on devra entre autres monitorer l'étal de conscience et la fréquence respiratoire. Nous avons toutefois besoin d'études complètes et d'autres histoires de cas pour nous faire une idée précise des avantages et des inconvénients de cette technique dans un contexte de travail.

L'analgésie est importante pour la parturiente et son fœtus et à ce titre, les experts en analgésie doivent connaïtre des alternatives à l'épidurale. Mandé tôt en consultation, l'anesthésiste pourra choisir le mode d'analgésie approprié. Les patientes motivées pourront souvent utiliser avec bonheur des méthodes non-pharmacologiques au début du travail mais elles devront parfois s'en remettre plus tard à des modes d'analgésie plus puissants. Les morphinques en mode d'autoanalgésie représentent une option valable à condition de surveiller adéquatement la mère et le nouveau-né.

\section{References}

I Melzack $R$. The myth of painless childbirth. Pain 1984; 19: 321-7.

2 Bonica JJ. Pain of parturition. Clinical Anesthesiology 1986; 4: 1-31.

3 Orser B. Obstetrical epidural anaesthesia in a Canadian outpost hospital. Can J Anaesth 1988; 35: 503-6.

4 Palahniuk RJ. Obstetrical epidural anaesthesia in remote hospitals. Can J Anaesth 1988; 35: 448-50.

5 Harrison RF, Woods $T$, Shore $M$, Mathews $G$, Unwin $A$. Pain relief in labour using transcutaneous electrical nerve stimulation (TENS). A TENS/TENS placebo controlled study in two parity groups. Br J Obstet Gynaecol 1986: 93: 739-46.

6 Crawford JS. General analgesia and anaesthesia in obstetrics. Clinical Anesthesiology 1986; 4: 157-69.

7 Abboud TK, Raya J, Noueihid R, Daniel J. Intrathecal morphine for relief of labor pain in a parturient with severe pulmonary hypertension. Anesthesiology 1983; 59 : 477-9.

8 Abouleish E. Apnoea associated with the intrathecal administration of morphine in obstetrics - a case report. Br J Anaesth 1988; 60: 592-4.

9 Kleiman SJ, Tessler MJ, Wiesel S. Patient-controlled analgesia (PCA) using fentanyl in a parturient with a platelet function abnormality. Can J Anaesth 1991; 38: this issue.
10 Eisenach JC, Grice SC, Dewan DM. Patient-controlled analgesia following cesarean seclion; a comparison with epidural and intramuscular narcotics. Anesthesiology 1988; 68: 444-8.

II Rayburn WF. Smith CV, Parrioll JE, Woods RE. Randomized comparison of meperidine and fentanyl during labor. Obstet Gynecol 1989; 74: 604-6.

12 Craft JB, Coaldrake LA, Bolan JC et al. Placental passage and uterine effects of fentanyl. Anesth Analg 1983; 62: 894-8.

13 Rayburn W, Rathke A, Leuschen P, Chleborad J, Weidner $W$. Fentanyl citrate analgesia during labor. Am J Obstet Gynecol 1989; 161: 202-6. 